вимагає нових підходів у викладанні відповідних дисциплін, тому формування знань у галузі спеціалізації має поєднуватися 3 набуттям практичних навичок роботи на комп’ютерах під час розв'язання професійних завдань [3].

Підсумовуючи вищезазначене, можемо зробити висновки, що в навчальному процесі використовуються сучасні методичні матеріали. Зростання інформаційних технологій, використання обчислювальної техніки зумовлює постійну зміну форм організації навчального процесу і використовуваних методичних матеріалів. Питання підготовки кваліфікованих фахівців є для вітчизняної виробничої галузі одним 3 ключових.

Для того щоб рівень підготовки випускників відповідав сучасним вимогам, ВН3 необхідно вдосконалювати й актуалізувати навчальні програми як у галузі інформатики загалом, так і в частині дисциплін, присвячених практичним питанням автоматизації підприємств. Якщо автоматизація власне бухгалтерського обліку або маркетингу викладається широко, то, наприклад, постановці первинного, оперативного або торгового обліку в програмах ВН3 приділяється поки що недостатньо уваги, хоча на практиці ці спеціальності затребувані.

\title{
Література
}

1. Башкаева Э. Х. Разработка профессионально значимых качеств у студентов / Э. Х. Башкаева // Личностно-ориентированный подход в воспитании и образовании. 2011. - С. 86-92. 2. Беспалько В. П. Педагогика и прогрессивные технологии обучения / В. П. Беспалько. - М. : ИРПО, 2005. - 332 с. З. Кикоть В. Я. Проблемы управления и пути развития профессиональной подготовки слушателей вузов : [монография] / В. Я. Кикоть. - СПб. : Санкт-Петербургская академия МВД России, 1997. - 205 с. 4. Кузьмина Н. В. Методы исследования педагогической деятельности / Н. В. Кузьмина. - СПб. : Машиностроение, 1999. - 302 с.

УДК: 371.937

Наталя Колесниченко

\section{КОНЦЕПЦІЯ МОДЕРНІЗАЦЇ̈ ПРОФЕСІЙНОЇ ПІДГОТОВКИ БАКАЛАВРІВ РОМАНО-ГЕРМАНСЬКОЇ ФІЛОЛОГІЇ НА ЗАСАДАХ КОМПЕТЕНТНІСНОГО ПІДХОДУ}

Колесниченко Н. Ю. Концепція модернізації професійної підготовки бакалаврів романо-германської філології на засадах компетентнісного підходу.

У статті висвітлено проблеми вдосконалення професійної підготовки бакалаврів романо-германської філології. Приділено увагу проектуванню концептуальної моделі модернізації професійної підготовки бакалаврів романо-германської філології на засадах компетентністного підходу. Уточнено провідні етапи, загальнодидактичні та специфічні принципи організації означеного процесу.

Ключові слова: модернізація, професійна підготовка, бакалаври романогерманської філології, компетентністний підхід, лінгвокомунікативна компетентність.

Колесниченко Н. Ю. Концепция модернизации профессиональной подготовки бакалавров романо-германской филологии на основе компетентностного подхода.

В статье отражены проблемы совершенствования профессиональной подготовки бакалавров романо-германской филологии. Уделяется внимание проектированию концептуальной модели модернизации профессиональной подготовки бакалавров романо-германской филологии на основе компетентностного подхода. 
Конкретизированы основные этапы, общедидактические и специфические принципы организации данного процесса.

Ключевые слова: модернизация, профессиональная подготовка, бакалавры романо-германской филологии, компетентностный подход, лингвокоммуникативная компетентность.

Kolesnichenko N. Yu. The concept of modernization of professional training of bachelors of Romance-Germanic Philology based on competence approach.

The article is focused on the problems of improving the professional training of bachelors of Romance-Germanic Philology. Particular attention is paid to the design of a conceptual model of modernization professional training of bachelors of RomanceGermanic Philology with competence-based approach being its ground. Main phases, general didactic and specific principles necessary for the organization of this process are highlighted.

Key words: modernization, professional training, bachelors of Romance-Germanic Philology, competence-based approach, lingua-communicative competence.

Згідно з документами Ради Свропи упродовж розвитку Болонського процесу підхід до визначення сутності результату освіти як можливої основи формування загального розуміння змісту кваліфікацій і ступенів став визначальним. У проекті «Налаштування освітніх структур» пріоритетним напрямком спільних зусиль подане визначення загальних і спеціальних компетенцій випускників першого та другого циклів (рівнів) навчання, під якими мають на увазі ступені бакалавра й магістра. Це означає, що компетентнісний підхід в освіті з'явився й розвивається як альтернатива традиційному - когнітивно-знаннєвому підходу, оскільки так звана «ЗУНівська» парадигма втрачає свій потенціал у системі освіти. По-перше, це пояснюється тим, що в сучасних умовах значно швидше відбувається старіння інформації, ніж завершується період навчання в середній чи вищій школі. По-друге,компетентнісний підхід відображає зміни й розуміння змісту освіти, який вже не грунтується на компоненті ЗУН (знань, умінь, навичок), а передбачає опанування тими, хто навчається, важливих ключових функцій, (щодо різних сфер. Через це пріоритет компетентнісного підходу в системі вищої освіти забезпечує не економічне зростання певної країни, а, передовсім, рівень всебічної розвиненості та освіченості особистості.

Із галузі локальної педагогічної теорії компетентнісний підхід в освіті поступово перетворюється на суспільно значуще явище, що претендує на роль концептуальнометодологічної основи сучасної європейської освітньої політики. Йдеться про те, щоб здійснити системну модернізацію європейської освіти задля узгодження на «компетентнісній» основі цілей, змісту, форм, методів і прикінцевих результатів професійної підготовки фахівців, які навчаються в бакалавраті та магістратурі.

Компетентнісний підхід передбачає не конкретну обізнаність та поінформованість випускників бакалаврату, а успішне розв'язання ними складних проблем, що виникають у процесі опанування нових сучасних інформаційних технологій, у стосунках з іншими, у практичному житті під час виконання соціальних і професійних ролей. Такий підхід в освіті пов'язаний 3 концепцією особистіснозорієнтованого навчання, оскільки грунтується на особистості бакалавра та може бути реалізованим і перевіреним тільки у процесі виконання певного комплексу дій. При цьому важливими є вміння не тільки оперувати засвоєними знаннями, а й бути 
готовим змінюватися і пристосовуватися до нових потреб ринку праці, управляти інформацією, активно діяти, швидко приймати рішення, навчатись протягом життя. Загальною ідеєю компетентнісного підходу $є$ компетентнісно-зорієнтована освіта бакалаврів, спрямована на комплексне опанування знань та способів практичної діяльності, що сприяють успішній реалізації суб'єкта в різних галузях життєдіяльності. Відтак компетентнісний підхід означає переорієнтацію 3 процесу навчання на результат саме у діяльнісному вимірі [1, с. 45]. Між тим, попри низку досліджень українських науковців (В. Баркасі, Н. Бібік, Л. Голубенко, Т. Дороніна, О. Овчарук, О. Пометун, О. Савченко, С. Скидан, О. Цокур, Г. Штельмах), досвід компетентністної освіти бакалаврів романо-германської філології, а також перехід способів організації їх професійної підготовки на засади компетентністного підходу, висвітлено недостатньо.

3 огляду на нові виклики часу щодо поліпшення вищої лінгвістичної та іншомовної педагогічної освіти мета статmі полягає в обгрунтуванні концептуальної моделі професійної підготовки бакалаврів романо-германської філології на засадах компетентністного підходу.

У сучасній педагогіці вищої школи компетентнісний підхід розглядається як нова дидактична парадигма й пріоритетний принцип організації професійної освіти бакалаврів, що зумовлюють орієнтацію змісту їх освіти на прикінцевий результат формування певних компетенцій як готовності й здатності фахівця виконувати визначені види діяльності, працювати ефективно й відповідально, згідно з чітко сформульованими вимогами [2, с. 37]. Через це компетентнісний підхід у системі професійної освіти найглибше відображає модернізаційні процеси, що нині мають місце в усіх країнах Європи. Аналіз спроектованих європейськими та українськими вченими компетентнісних моделей фахівців засвідчує, що, по суті, вони виходять із подібної концепції, оскільки 3 наявного різноманіття визначають чотири види ключових компетенцій:

- інструментальні, - включають в основному початкові здібності, базові загальні знання й загальні знання за професією;

- міжособистісні, - описують готовність до соціальної взаємодії, уміння працювати в групі, здатність до самокритики, прихильність етичним цінностям, толерантність;

- системні, - відбивають здатність системно застосовувати отримані знання на практиці, здійснювати дослідження, генерувати нові ідеї, адаптуватися до нових ситуацій тощо;

- спеціальні, - характеризують володіння предметною галуззю на певному рівні [2, с. 68].

Наявність різноманітних шляхів упровадження компетентнісного підходу в професійну освіту є свідченням багатогранності проблеми. Компетентнісний підхід означає спрямованість освітнього простору на формування та розвиток ключових $\mathrm{i}$ предметних компетентностей особистості; переорієнтацію 3 процесу на результат освіти в діяльнісному вимірі та розгляд із позиції забезпечення спроможності майбутнього фахівця відповідати новим запитам ринку праці. Запровадження компетентнісного підходу в систему професійної освіти дає змогу ліквідувати розрив між когнітивним, діяльнісним та особистісним рівнем розвитку майбутнього фахівця. «Компетенція» розглядається як освітній результат, як сукупність взаємопов'язаних якостей особистості (знань, умінь, навичок, способів діяльності), які задаються стосовно певного кола предметів і процесів та $\epsilon$ необхідними для якісної 
продуктивної дії. «Компетентність» - інтегральна характеристика особистості, що визначає володіння відповідними знаннями і здібностями, які дають змогу ефективної взаємодії [2, с. 44].

В означеному контексті слід зазначити, що незважаючи на дослідження окремих видів компетенцій, що входять до структури лінгвокомунікативної та професійної компетентності випускників спеціальності 6.020303 «Мова і література» (англійська, німецька, французька, іспанська), що здійснювалося переважно в галузі методики викладання іноземних мов, проте загальнодидактичні й лінгводидактичні питання, пов'язані 3 науково-методичним забезпеченням процесу їх навчання на засадах компетентнісного підходу, дотепер залишаються дискусійними й остаточно не визначеними [3, с. 140]. Ураховуючи актуальність означеного аспекту проблеми, що зумовлено динамікою розвитку Болонського процесу і реалізацією провідних цілей Україною в напрямі досягнення нової якості освіти на основі отримання випускниками вищих навчальних закладів ключових, предметних, соціальних, особистісних і професійних компетенцій і компетентностей, розпочато проектування моделі модернізації професійної підготовки бакалаврів романо-германської філології на засадах ідей компетентнісного підходу, що здійснюється вперше.

Спираючись на загальнометодологічний принцип цілісності і системності, процес професійної підготовки бакалаврів романо-германської філології на засадах компетентнісного підходу сприймався нами як цілісна дидактична система, що динамічно розвивається і складається із взаємозумовлених i взаємопов'язаних елементів, які зазнають впливу чинників зовнішнього соціокультурного середовища, зокрема інтеграції в європейський науково-освітній простір. Для цього спеціально проаналізовано й узагальнено необхідні відомості про досліджуваний процес, які ретельно добиралися в результаті вивчення наукової літератури та власних спостережень за особливостями перебігу реального навчально-виховного процесу, що забезпечує професійну підготовку бакалаврів романо-германської філології, у тому числі провідних суперечностей і ускладнень та ін.

Так, основою організації процесу професійної підготовки бакалаврів романогерманської філології на засадах ідей компетентнісного підходу як особливої дидактичної системи є стратегічна мета, яка полягає у формуванні їх професійної компетентності як майбутніх суб'єктів царин міжкультурної комунікації та шкільної іншомовної освіти. Це означало сприйняття випускників бакалавріату як кваліфікованих фахівців, які вільно володіють професією, здатних на творчу працю у міжкультурній комунікації, перекладацьких та освітніх послуг на рівні європейських стандартів, готових до постійного особистісно-професійного зростанням, соціальної і професійної мобільності.

Визначивши мету професійної підготовки бакалаврів романо-германської філології на засадах компетентнісного підходу у вигляді отримання особливого освітнього продукту - професійної компетентності, ми, тим самим, виконали першу вимогу компетентнісного підходу. Остання передбачає здійснення моніторингу якості професійної освіти на принципово новій основі - крізь призму нової базової категорії «компетентність» (на відміну від традиційного когнітивно-знаннєвого підходу, зорієнтованого на оцінку якості знань, умінь і навичок).

Крім того, спираючись на результами досліджень, які стосуються навчання студентів першого циклу вищої освіти в контексті перспектив євроінтеграції [3; 4], конкретизовано, організацію процесу професійної підготовки бакалаврів романогерманської філології на засадах ідей компетентнісного підходу зумовлену такими 


\section{чинниками:}

- соціально-економічними перетвореннями, що відбуваються в українському суспільстві, структурним реформуванням вітчизняної системи вищої лінгвістичної й іншомовної педагогічної освіти згідно болонських вимог;

- зумовленістю цього процесу від кон'юнктури ринку міжкультурних комунікацій, перекладацьких й освітніх послуг, зміни функцій і видів спеціалізації діяльності 3 використання іноземних мов, зростаючих вимог суспільства до представників цих професій;

- наявними інформаційно-технічними, кадровими i фінансово-матеріальними ресурсами вищої школи, а також педагогічними та дидактичними умовами тощо.

Відповідно, проектування моделі модернізації професійної підготовки бакалаврів романо-германської філології на засадах компетентнісного підходу передбачалося здійснення на підставі реальних науково-освітніх ресурсів, наявних на основних базах дослідження, а також певних можливостей для здійснення інноваційно-педагогічної діяльності.

Основою і системоутворювальним елементом моделі модернізації професійної підготовки бакалаврів романо-германської філології на засадах компетентнісного підходу є мета, що зумовлює функціонування іiі провідного - цільового компонента, згідно з яким означена дидактична система спрямована на формування їх професійної компетентності. При чому означена мета, передбачаючи використання дидактичних ресурсів i можливостей компетентнісного підходу до організації навчання, конкретизована за допомогою постановки низки завдань:

- оволодіння бакалаврами романо-германської філології фундаментальними теоретичними знаннями, що дають цілісне уявлення про зміст, структуру і функції лінгвістичної, перекладацької й лінгводидактичної діяльності, провідних технологій їх здійснення;

- засвоєння ними провідних способів професійного мислення і практичних дій, необхідних для успішного виконання завдань міжкультурної, перекладацької й педагогічної діяльності з використанням іноземних мов у професійних цілях;

- актуалізація потреби у професійному самопізнанні, самовизначенні i самовихованні майбутніх фахівців галузі міжкультурної комунікації, перекладацького сервісу, лінгводидактичних технологій;

- стимулювання пізнавальної мотивації щодо набуття необхідних для успішної професійної діяльності предметних, соціальних, індивідуальних і персональних компетенцій.

Дотримуючись настанов визнаних дидактів вищої школи щодо застосування засобів системного підходу до опису і пояснення дидактичних явищ (В. Бондар, А. Вербицький, І. Кобиляцький, Л. Кондрашова та ін.), модель модернізації професійної підготовки бакалаврів романо-германської філології на засадах компетентнісного підходу подано як цілісну систему, що має певні взаємозв'язані структурні компоненти - цільовий, мотиваційно-стимулювальний, змістовнотехнологічний і результативний.

Другим функціональним компонентом пропонованої моделі $\epsilon$ мотиваційностимулювальний, що грунтується на механізмі дидактичної взаємодії бакалаврів романо-германської філології з викладачами в контексті забезпечення їх професійної підготовки. Так, згідно з настановами компетентнісного підходу, позиція викладача повинна перетворитися 3 формальної (носій навчальної інформації, передбаченої освітнім стандартом спеціальності «Мова і література») i пасивної (транслятор 
інформації) на дієву (носій соціокультурних цінностей і різних компетенцій) $\mathrm{i}$ активну (організатор і менеджер лінгвістичної й іншомовної педагогічної освіти). Це, по-перше, передбачало зміну власне дидактичних пріоритетів викладачів, оскільки головним у процесі навчання $є$ не предмет, а особистість, що здобуває відповідних компетенцій і компетентностей. По-друге, компетентнісний підхід, як зазначає О. Цокур, передбачає зміну професійно-педагогічних пріоритетів викладача вищої школи, оскільки вимагає доповнення його провідних професійних функцій як мовного і наукового консультанта та організатора навчально-пізнавальної діяльності бакалаврів і співробітництва, новими аспектами діяльності в галузі освітнього сервісу:

- функцій маркетолога, який вивчає пропозиції на ринку професійної праці бакалаврів романо-германської філології та попит на лінгвістичну й іншомовну педагогічну освіту на ринку освітніх послуг;

- функцій підприємця в царині освітнього бізнесу, що, ураховуючи нові вимоги роботодавців у сфері міжкультурної комунікації, перекладацьких й освітніх послуг, здійснює пошук і впровадження педагогічних інновацій у процес навчання майбутніх бакалаврів романо-германської філології;

- функцій діагноста, який спостерігає за динамікою формування професійної компетентності майбутніх бакалаврів романо-германської філології та здійснює вимір рівнів їі сформованості;

- функцій диспетчера-адміністратора, що здійснює корекцію й моніторинг якості процесу навчання бакалаврів романо-германської філології та прикінцевих результатів ïx лінгвістичної, перекладацької й іншомовної педагогічної освіти [6, с. 234].

Відповідно до змінених позицій і ролей викладача, у процесі навчання бакалаврів романо-германської філології на засадах компетентнісного підходу, на нашу думку, мають відбутися кардинальні зміни. Передовсім це зміна об'єктної позиції (пасивне сприймання інформації, формальна участь у групових формах комунікації, заучування навчальних текстів, репродуктивне їх відтворення тощо) бакалаврів романогерманської філології на суб'єктну в процесі навчання. Остання, як мінімум, передбачає:

- усвідомлення бакалавром романо-германської філології особистої значущості набуття необхідних для майбутньої професійної кар'єри та життєдіяльності ключових, базових, соціальних, предметних компетенцій i професійної (лінгвістичної, соціокультурної, соціально-психологічної, інформаційно-інформативної, іншомовнопедагогічної, лінгводидактичної та перекладацької) компетентності під час навчання у вищому навчальному закладі;

- виявлення майбутніми бакалаврами романо-германської філології освітньої компетенції (такого рівня розвитку особистості, який пов'язаний 3 якісним опануванням змісту лінгвістичної, перекладацької й іншомовної педагогічної освіти (мобільні знання, що постійно оновлюються, дієві методи, які дають змогу використовувати ці знання в конкретній ситуації; критичне мислення, що дозволяє оцінювати певні ідеї щодо можливості їх використання в тій чи тій ситуації);

- здійснення бакалаврами романо-германської філології самостійної пошукової, науково-дослідницької та творчої діяльності як менеджерів самоосвітнього процесу (за рахунок опанування провідних функцій самоменеджменту) на грунті виявлення пізнавальної ініціативи, інтелектуально-мовленнєвої й соціальної активності, демонстрації вмінь з'ясовувати суперечності; виявляючи критичне мислення, висловлювати гіпотези, узагальнювати, формулювати висновки.

Саме для цього, за нашим припущенням, проектування моделі модернізації 
професійної підготовки бакалаврів романо-германської філології на засадах компетентнісного підходу вимагало узгодження відповідних до іï стратегічної мети i завдань принципів навчання, що регулювали механізм дидактичної взаємодії в мікросистемі «викладач - бакалавр романо-германської філології, який набуває професійної компетентності». У зв'язку 3 цим функціонування мотиваційностимулювального компоненту професійної підготовки бакалаврів романо-германської філології на засадах компетентнісного підходу здійснювалося $з$ урахуванням таких принципів їх навчання:

- єдності науково-дослідної, навчально-пізнавальної та освітньо-виховної діяльності студентів;

- професійної спрямованості, що передбачає перехід від навчальної діяльності студента до професійної діяльності фахівця;

- професійної мобільності;

- мажорності процесу навчання.

Тому поміж загальнодидактичних принципів організації професійної підготовки бакалаврів романо-германської філології на засадах компетентнісного підходу, під якими розуміємо провідні ідеї, покладені в основу професійно-педагогічної діяльності викладачів вищої школи, окреслено такі:

- принцип свідомості й активності навчання, що передбачає усвідомлення індивідуальної значущості компетенцій, які набуваються майбутніми бакалаврами впродовж вивчення загальнонаукових, соціально-гуманітарних i спеціальних дисциплін для успішності їх життєдіяльності й реалізації здобутих компетенцій;

- принцип науковості та системності, що передбачає набуття фундаментальної теоретичної і практичної підготовки майбутніх бакалаврів до професійної самореалізації на ринку міжкультурних, іншомовних, перекладацьких, освітніх послуг на підставі цілісного уявлення про сутність і структуру, а також функції та провідні технології професійної діяльності фахівця-філолога у галузі використання іноземних мов;

- принцип проблемного викладу навчального матеріалу i діалогізації дидактичного спілкування в системі «бакалавр - викладач» і «бакалавр - бакалавр», що передбачає тренінг їх інтелектуальних і професійних функцій майбутніх фахівців сфери міжкультурної, іншомовної й педагогічної комунікації в нестандартних ситуаціях та набуття ними досвіду творчої діяльності;

- принцип ігрового моделювання предметного i соціального контекстів (А. Вербицький [1]) майбутньої професії фахівця сфери романо-германської філології (що забезпечує послідовний перехід від навчально-пізнавальної через квазіпрофесійну та навчально-професійну до професійної - міжкультурної, іншомовної мовленнєвої, перекладацької діяльності (К. Шапошников [7]) і рольової перспективи (Л. Кондрашова [4]);

- принцип єдності навчання, наукового дослідження та виховання особистості майбутнього бакалавра романо-германської філології як професіонала, що забезпечує його мобільність у виборі місця працевлаштування, варіативніть у виборі професійної кар'єри та самовизначення у царині міжкультурної комунікації, перекладацьких й іншомовно-педагогічних послуг в ринкових умовах праці.

Прикінцевим результатом модернізації професійної підготовки бакалаврів романо-германської філології на засадах компетентнісного підходу повинен стати досить високий рівень сформованості їх професійної компетентності у єдності двох провідних складників: професійно-лінгвістичної та професійно-педагогічної 
компетентності. Останні тлумачаться основним критерієм оцінки якості лінгвістичної й іншомовної педагогічної освіти бакалаврів, а також досконалості особистості в реалізації основних професійних функцій.

Отже, з огляду на нові виклики часу щодо подальшого розвитку європейського освітнього простору, до якого тяжіє вітчизняна система вищої лінгвістичної та іншомовної педагогічної освіти, як альтернативу традиційному виду навчання нами розроблена модель модернізації професійної підготовки бакалаврів романогерманської філології на засадах нового - компетентнісного підходу, спрямованого на формування їх професійно-лінгвістичної та професійно-педагогічної компетентності. Саме остання визнана європейською педагогічною спільнотою провідним критерієм якості вищої освіти фахівців іноземних мов і присудження відповідних кваліфікацій.

Перспективи подальших розвідок убачаємо в конкретизації професійно важливих якостей бакалавра романо-германської філології як мовної особистості.

\section{Література}

1. Вербицкий А. А. Компетентностный подход и теория контекстного обучения / А. А. Вербицкий. - М. : Исследоват. центр проблем качества подгот. спец., 2004. 136 с. 2. Компетентнісний підхід у сучасній освіті : світовий досвід та українські перспективи : бібліотека 3 освітньої політики: [монографія] / Н. М. Бібік, Л. С. Ващенеко, О. І. Локшина, О. В. Овчарук, Л. І. Паращенко, О. І. Пометун, О. Я. Савченко та ін.; під заг ред. О. В. Овчарук. - К. : К. І. С., 2004. - 112 с. 3. Компетентность человека - новое качество образования : материалы XIII Всерос. совещания; под ред. А. В. Хуторского. - М.; Уфа: Исследоват. центр проблем качества подгот. спец. - 2003. - Кн. 2. - 72 с. 4. Кондрашова Л. В. Высшая педагогическая школа и Болонский процесс : реалии и перспективы : [монография]/ Лидия Валентиновна Кондрашова. - Кривой Рог: КГПУ, ИВИ, 2007. - 474 с. 5. Краковская О. С. Модель формирования организационно-управленческой компетенции бакалавров лингвистики / О.С. Краковская // Вестник Балтийского федерального университета им. И. Канта. - 2014. - Вып. 2. - С. 138-144. 6. Цокур О. С. Категория педагогического сознания в теории и практике профессиональной подготовки учителя : дис. ... доктора пед. наук : 13.00.04 / Ольга Степановна Цокур. - Одесса, 1998. - 464 с. 7. Шапошников К. В. Контекстный подход в процессе формирования профессиональной компетентности будущих лингвистовпереводчиков : дис. ... канд. пед. наук: 13.00.08/ Константин Владимирович Шапошников. - Йошкар-Ола, 2006. - 226 с.

\section{ПЕРСПЕКТИВНІ НАПРЯМКИ ВИКОРИСТАННЯ ІНФОРМАЦІЙНО- КОМУНІКАЦЙНИХ ТЕХНОЛОГІЙ У НАВЧАЛЬНОМУ ПРОЦЕСІ}

Коробань О. В. Перспективні напрямки використання інформаційнокомунікаційних технологій у навчальному процесі.

У статті окреслено основні тенденції інформатизації освітньої галузі в сучасних умовах. Відображено основні потреби особистості у своєму розвитку. Розглянуто основні перспективні напрями розробок і використання засобів IКТ.

Ключові слова: інформатизація, інформаційні технології, комп'ютерні технології, освіта, навчальний процес. 